\title{
Exchange rate management techniques
}

\author{
DANIELA MAGALHÃES PRATES*
}

This briefing note addresses the question: What revisions of financial regulation and financial governance in Brazil are necessary to support Brazilian development? What's in place and what's missing? The focus here is a dimension of financial regulation and governance: the regulation of capital flows and of exchange rate operations.

The arguments are organized as follows. The next section summarizes the impacts of the global financial crisis of 2008-2009 on the emerging-market economies $^{1}$ and on the regulation of the international monetary and financial systems. The third section discusses the post-crisis dilemmas faced by these economies. Finally, the fourth section presents some policy recommendations for Brazil.

\section{AN OPPORTUNITY WINDOW WAS LOST}

The financial crisis, which started in mid-2007 with soaring insolvencies and the devaluation of real estate and assets related to high-risk (subprime) mortgages in the United States, reached systemic proportions in the third quarter of 2008, following the bankruptcy of many banking and non-banking institutions (mainly, Lehman Brothers on 15 September 2008). By means of deleveraging and/or flight to quality, the crisis spread to emerging-market economies (through many transmission channels) whose companies and banks had no connection with the securities linked to subprime mortgages. Because of the hierarchical and asymmetrical nature of the international monetary and financial system, these movements had much

\footnotetext{
* Professor at the Institute of Economics of the State University of Campinas and researcher at the National Council for Scientific and Technological Development (CNPq). This briefing note was written for the Workshop "Financial Stability and Financial Governance in Brazil - Assessing the Landscape and Drawing Policy Implications”, held in São Paulo on March 24 and 25, 2011.

${ }^{1}$ For the purposes of this note, emerging-market economies are peripheral countries which have been integrated in the financial globalization.
} 
greater destabilizing effects on the foreign exchange markets of these economies. Not even those ones with relatively solid macroeconomic fundamentals have remained untouched by the contagion effect of the crisis.

The importance of the degree of financial openness was made clear by the different impacts of the crisis on the exchange rates of emerging-market countries. These impacts were more significant not only in countries such as South Africa and Turkey, which had high current-account deficits, but also in those that increased their degree of financial openness during the phase of abundant international liquidity (2003-2007) and absorbed significant amounts of speculative capital inflows (and/or allowed hedging and speculative transactions on the foreign exchange derivative markets). South Korea and Brazil, which suffered strong devaluations in the last quarter of 2008 (the crisis' worst period), belong to this latter group. They were significantly affected by the crisis in spite of their current-account surpluses in 2007 (which turned into deficit in 2008) and their huge international reserves (see Figure 1).

Figure 1: Exchange rate variations (from 09/15/2008 to 12/31/2008)

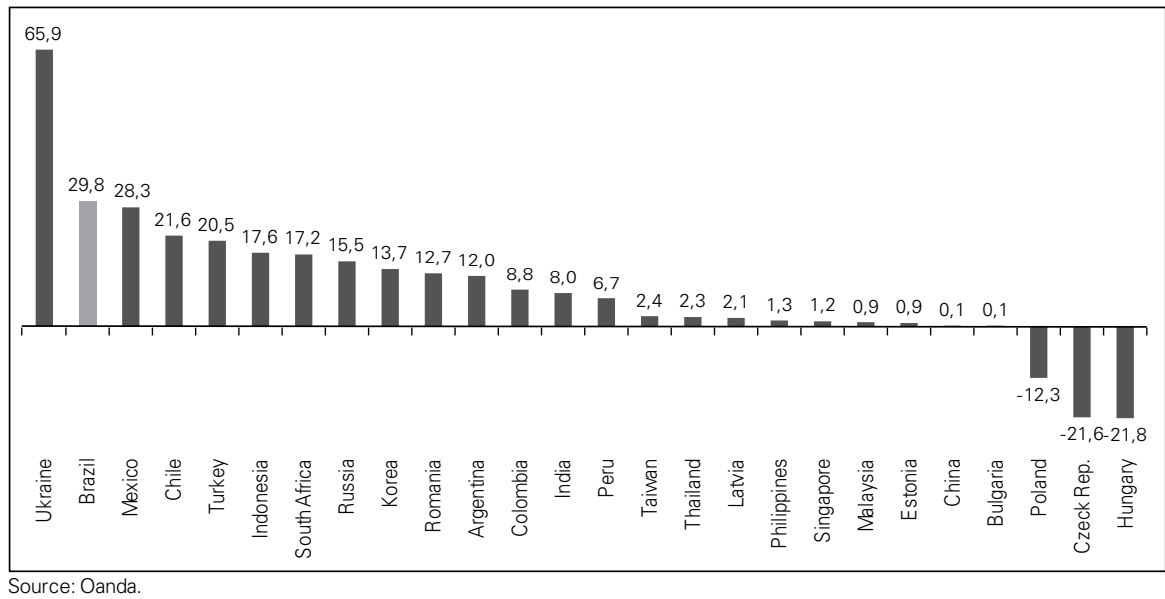

The Brazilian economy, better protected than at other moments of global turbulence, was touched by many contagion effects, largely associated with its high degree of financial openness, which has allowed foreign investors unrestricted access to the spot and derivative segments of its domestic financial markets.

First, the maturities of international credit lines were cut short and interest rates were raised, making access to new loans for working capital and investment more difficult. Brazilian banks and companies started encountering difficulties in accessing external credit lines, even to support foreign trade operations, which are considered low risk. According to Brazil's central bank, short-term credit lines including those for imports and exports - amounted to US\$ 46.1 billion in August 2008. If considered together with the operations of the multinational companies in 
the country, which amounted to US\$ 59 billion, this represents a considerable amount of foreign resources that were fuelling the Brazilian economy. Second, the devaluation of stocks traded in the São Paulo Stock Exchange (Bovespa) reduced the price of companies' assets (to 1 trillion Brazilian real as in October 2008). Third, the weakening of advanced economies reduced the demand for Brazilian exports, many of which have also suffered from a fall in commodity prices.

Fourth, the Brazilian currency registered a sharp devaluation due to the flight of foreign investors and to major losses incurred by 220 companies (mostly, exporters) which had performed high-risk operations in both the domestic foreign exchange derivative market (which are undertaken in Brazilian real) and the international foreign exchange derivative market (where non-deliverable forwards (NDFs) are negotiated). These operations were performed in the context of an uninterrupted appreciation of the Brazilian currency since 2003, with the aim of offering protection to the estimated amount of exports against devaluation, or of obtaining speculative gains (if the value of the operation surpassed the exports), or of reducing the cost of bank loans ${ }^{2}$.

Therefore, the global financial crisis showed that the adoption of prudent macroeconomic policies and the accumulation of foreign currency reserves (the "precautionary demand" for reserves) by emerging-market economies after the crisis of the 1990s have been insufficient to immunize them against the systemic risks inherent to financial globalization, among which the greater volatility of their exchange-rates in comparison with centre countries.

In order to understand the behaviour of exchange rates in these countries, it is necessary to take into account their specific position in the contemporary international monetary system ${ }^{3}$. This system comprises a hierarchical and asymmetrical institutional arrangement organised around a key currency, as pointed out by Keynes during the debates preceding Bretton Woods (Keynes, 1980). Besides the superior position of the key currency (the fiduciary dollar in the current system), placed at the top of the currency hierarchy (and, for that reason, the most liquid currency), the international monetary and financial system is marked by asymmetries cutting across the currencies of the centre countries and those of emergingmarket countries, which conditions the behaviour of currency markets in the latter.

Monetary and financial asymmetries have two important consequences for the dynamics of the foreign exchange market of emerging-market countries. First, these markets are particularly vulnerable to the inherent volatility of capital flows. At times (as in the fourth quarter of 2008) of a reversal of the economic cycle and of an increase in the preference for liquidity and in the risk aversion of global investors, financial assets of emerging-market economies (that do not play the role of store of value in the international system) are the first to be sold by global investors.

\footnotetext{
${ }^{2}$ The terms centre, advanced and developed countries (or economies) are used as synonyms.

${ }^{3}$ For a detailed analysis of the crisis impact on Brazil and emerging-market countries, see Prates and Cintra (2010).
} 
In contrast, during the booms of international liquidity cycles, when the appetite for risk is high (i.e., when the animal spirits of investors are more pronounced), "emerging-market assets" become objects of desire on the part of global investors because of the expectation of appreciation of their respective currencies (associated with the favourable interest rate and/or with the perspective of capital gains in the stock markets), compensating for their reduced liquidity premium.

Second, the fact that these markets account for only a marginal proportion of capital flows also contributes to their greater volatility. This is so because the degree of instability of investments is generally higher for foreign than for domestic assets and, in the case of assets of emerging-market economies, this instability is still more pronounced as a result of the equally marginal effects of the sale of these assets on the profitability of global portfolios. However, in spite of their residual nature, the potentially destabilizing effects of capital flows on the emerging-market economies' exchange and financial markets are considerable, given that, in relation to the size of these markets, the volume allocated by global investors is not marginal. Because these markets are not very liquid and deep, sales by these investors can result in currency depreciations and significant reductions in the prices of assets, with potentially harmful effects on other segments of the financial market, as well as on the macroeconomic dynamics and on the level of activity. Such effects are also related to the so-called currency mismatch in the balance sheets of banks, companies and governments that hold debt in foreign currency, which is one of the consequences of monetary asymmetry.

However, although the systemic dimension of the crisis opened an opportunity window to the adoption of a structural reform in the international monetary and financial system (as proposed by Keynes), changes in the regulatory mechanisms adopted so far (Basle III and the reform of United Stated financial system) and the ones yet to happen (mainly, the European Union reform) will not result in this kind of reform. In fact, such changes have focused on the configuration of financial systems in developed countries without taking into account the hierarchical and asymmetrical nature of the international monetary and financial system and their negative implications for emerging-market countries, among which the vulnerability to the booms and bursts of capital flows and their negatives effects to the exchange rate movements.

Here it is important to remind Keynes's proposal at Bretton Woods Conference. One of this proposal's central elements was the reduction of the asymmetries between countries, so as to secure a more equitable distribution of the adjustment of external disequilibrium between those two groups of countries and contribute to expand the macroeconomic policy autonomy. For that purpose, besides suggesting the creation of the Clearing Union and the Bancor, Keynes (1980) strongly recommended that countries should be able to increase the effectiveness of their capital controls by cooperating in the enforcement of each other's regulations; in others words, cooperative capital controls (capital movements controlled at both ends) should be adopted (Helleiner, 1994). 


\section{THE POST-CRISIS POLICY DILEMMAS}

After the brief interruption in the fourth quarter of 2008 and early 2009, capital flows returned to emerging economies chasing for yields in the context of abundant liquidity and lower interest rates in advanced economies (consequence of the countercyclical monetary policies launched in response to the crisis). As before the crisis, the currencies of several emerging countries became, again, the target of carry trades due to the interest rate differentials. Moreover, the stronger recoveries in the emerging-market world contributed not only to higher rates of return but also to a perception among investors of declining risk. This monetary context in developed economies, rapid growth in the emerging ones (notably in China) and renewed speculation in commodity derivatives markets also gave rise to a new boom in commodity prices (Akyuz, 2011; BIS, 2010).

Thus, emerging countries have faced ${ }^{4}$ a new boom of international liquidity, the fourth one in the post-Bretton Woods era and the third one of the globalization $\mathrm{era}^{5}$, starting in the first half of 2009. Besides the post-crisis circumstances, this boom is also a manifestation and a consequence of the fact that no structural change on the International Monetary and Financial System was adopted on the crisis treadmill. Once more, "emerging-market assets" became objects of desire on the part of global investors, resuming policy dilemmas to the emerging countries stemming from the combination of high growth rates, accelerating inflation (associated with the new commodity prices boom), excessive exchange rate appreciation and/or asset price overshooting. In this scenario, the adoption of a restrictive monetary policy would help to contain growth and inflationary pressures, but would encourage further capital inflows, which, in turn, would foster the asset price boom and the exchange rate misalignment (see Figure 2). In the case of commodity exporters countries (as Brazil), this misalignment are reinforced by the commodity price boom which, in turn, contributes to sustain the current exchange rate $\left(e_{c}\right)$ below the industrial exchange rate $\left(\mathrm{e}_{\mathrm{I}}\right)^{6}$.

In order to deal with these dilemmas and try to achieve the multiple policy objectives, policy makers in emerging countries resorted to capital controls and prudential regulation mechanisms (instruments now recommended and accepted by the $\mathrm{IMF}^{7}$ ) to halt the trend of currency appreciation and/or the speculative bubbles in asset prices, while restrictive monetary and fiscal policies were adopted to slow the economy and contain inflationary pressures.

Thus, unlike the pre-crisis context, emerging-market countries (even those with current account deficits) are now unwilling to adopt a hands-off approach to cap-

\footnotetext{
${ }^{4}$ Maybe the boom has already burst due to the deterioration of international scenario in the third quarter of 2011 (caused by the worsening of the Euro crisis and the double dip threat).

${ }^{5}$ As pointed by Biancareli (2009), the two first cycles of the globalization era were: 1990-2002; 20032007.

${ }^{6}$ See Bresser-Pereira (2009).

${ }^{7}$ See: Blanchard et al. (2010) and Ostry et al. (2010).
} 
ital inflows. As after the crisis of the 1990s, these countries learned lessons from the global financial crisis, that showed the inability of the reserve accumulation to cushion them against the adverse effects of financial globalization as well as the potentially harmful effects excessive currency appreciation (as evident from the experiences of Brazil and the Republic of Korean). As pointed by Rodrik (2006, p. 12), during 2003-2007, these countries had "over-invested in the costly strategy of reserve accumulation and under-invested in capital account management policies." Furthermore, besides its fiscal cost, the use of this strategy to curb exchange rate appreciation can lead to faster credit growth and increases the risk of asset price overshooting, whose negative consequences became evident with the crisis.

It's worth to recalling that during the 1990s, up to the emerging countries crises, when the exchange rate managed regimes (fixed or exchange bands) prevailed, some of these countries adopted the same two kind of regulatory instruments, which integrated what Epstein, Grabel and Jomo (2004) called "Capital management techniques". These techniques include the traditional menu of capital controls but add a set of prudential financial regulations (as restrictions on banks operations in foreign currencies). Their research shows that there is often a great deal of synergy between prudential financial regulations and traditional capital controls: certain types of prudential financial regulations actually function as a type of capital control; moreover, capital controls themselves can function as or complement prudential financial regulations.

With the adoption of "dirty float" regimes by many emerging-market countries after the 1990's crises, a new role has emerged for the management of capital flows. These countries, actually, face an "impossible duality" (Flassbeck, 2001): the environment of financial globalization implies loss of economic policy autonomy, independently from the exchange regime adopted, because it reinforces the interrelation between interest rate and exchange rate, and the influence of the global investors portfolio decisions over these key-prices.

In the "dirty float" regimes, besides reducing these countries vulnerability to financial crises, the capital management techniques increases the degree of autonomy for economic policy-making and are a supporting instrument for the exchange rate and monetary policies in times of boom and burst of capital flows (in boom times, they reduce the destabilizing effects of short-term capital flows and the cost and risk of reserve accumulation; in burst times, they reduce the minimum level of reserves needed to restrain speculative movements and alleviate pressures in the domestic interest rate).

\section{BRAZIL'S SPECIFICITIES AND POLICY RECOMMENDATIONS}

The Brazilian experience prior to, during and post the global financial crisis sheds light on the policy challenges faced by the monetary authorities of the emerging-market countries concerning to the macroeconomic management within the current international monetary and financial system. In Brazil, two characteristics reinforce the economic policy dilemmas. 
On one hand, the reserve accumulation policy faces two important constraints: the significant amount of public debt concentrated in short term and the huge differential between internal and external interest rates, which make the sterilization operations cost excessively high, reducing the action range of the Central Bank in the exchange rate management. On the other hand, the high degree of financial openness of the Brazilian economy (which allows the access of the foreign investors to all the segments of the financial markets, including the financial derivative markets), and the existence of ample and deep financial markets, reduces even more the capability of the monetary authority to influence the determination of the exchange rate, as well as the formation of the interests curve. In fact, the operations with exchange rate derivatives, that are virtual transactions, have a central role in the trajectory of the R $\$ / U S \$$ exchange rate, unrelated with capital flows and therefore outside the scope of the "capital management techniques" ${ }^{8}$. These specificities largely explain the major appreciation of the Real during 2009 in the group of emerging countries (see Figure 2).

Figure 2: Exchange rates variation by groups of countries, selected periods (\%)

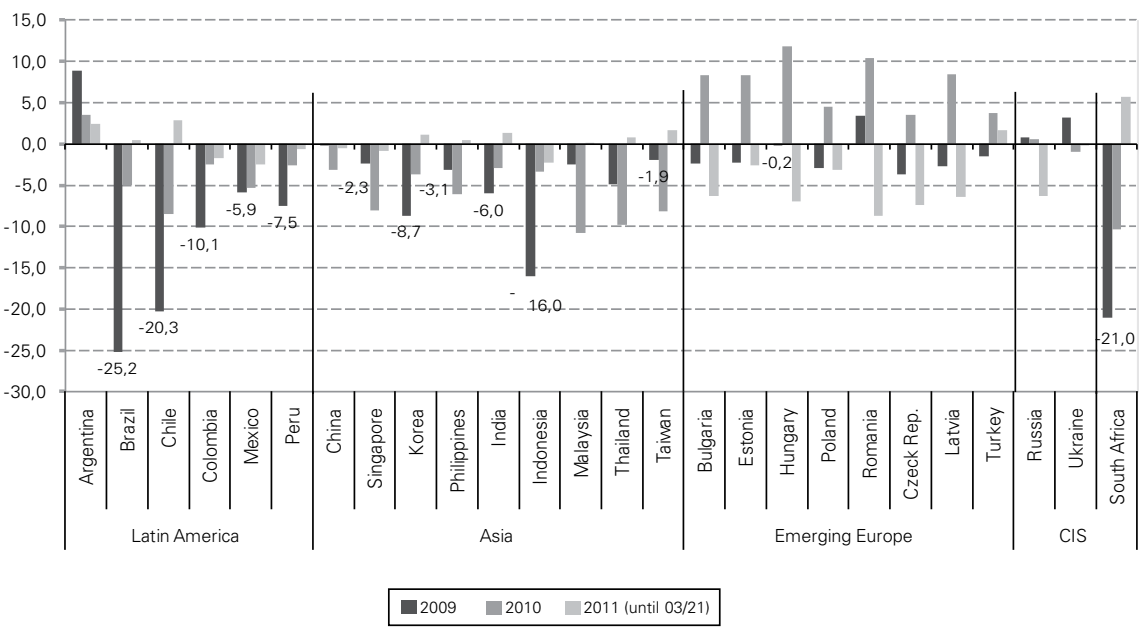

Source: Oanda.

Thus, besides the "Capital management techniques", the Brazilian policy makers need to use what here is referred to as "Exchange rate management techniques", whose focus is the virtual operations. In fact, the Brazilian economic authorities have already adopted (or reinforced) some of these two kinds of techniques, among which: in October 2010, a $2 \%$ tax (IOF) on portfolio investment was levied (and, some days after, increased two times - to $4 \%$ and $6 \%$ ) and the tax (also IOF) levied on initial margin in BM\&F (future market) was raised from $0.38 \%$ to $6 \%$;

\footnotetext{
${ }^{8}$ For a detailed analysis of this central role, see Prates and Farhi (2009).
} 
in January 2011, a compulsory deposit was levied on open positions in dollar carried by banks?.

However, the "Capital management techniques" and "Exchange rate management techniques" need to be much broader than the current ones and to become a permanent feature of the policy economic regime even if the policy mix undergoes changes that allow the reduction of the Brazilian interest rate. As structural changes in the international and monetary system was not adopted, the demand for "emerging market" assets and exchange rate appreciation pressures most probably will remain high in the future because the short-term nominal interest rate differentials in favor of the emerging-market countries are expected to persist or even to widen and those countries are expected to grow significantly faster than the advanced economies over the next ten years. Furthermore, the new commodity price boom and the high probability that these prices will remain high in the medium term also resulted in exchange rate appreciation pressures, as already pointed. In sum, these techniques, by affecting the economy's financial openness, widen the economic policy's degree of autonomy.

Regarding the "Capital management techniques", as the cooperative controls recommended by Keynes remain nonexistent, in order to be effective, they have to encompass all kinds of capital flows, and not only portfolio investments in the domestic financial market. The huge capital inflows to the Brazilian economy during the first quarter of 2011 (US\$ 34 billion against US\$ 24 billion in the same quarter of 2010) - despite the turbulences in the international financial markets - shows that the measures adopted so far had show limited effectiveness due to their narrow scope. In response to the compulsory deposit on dollar assets, banks, as capitalist institutions in search for yield, raised funds by issuing short-term securities abroad. Thus, a broader approach is needed to reduce the loopholes that financial capital finds to circumvent the regulations.

With respect to "Exchange rate management techniques", the ideal solution would be the revision of Resolution 2.689 (January, 2000), which allowed the access, without restrictions, of foreign investors to the financial derivative markets. The former regulation, that permitted this access only for hedge purposes, should come back. As the feasibility of this radical change is small (due to the opposite interests, mainly of financial agents), these techniques should throw sand in the wheels of foreign exchange virtual transactions.

As showed by the McCauley and Scatigna (2011), based on the last central bank survey of foreign exchange market activity, trading in the Brazilian real occurs mostly at home (onshore) and at the future market. Off-shore and over-the counter derivatives linked to the real exchange rate are not so important ${ }^{10}$. Thus, regulations should focus this market (the BM\&F), what make easier the task to policy markers. Besides the further increase of the $\operatorname{tax}(\mathrm{IOF})$ on the initial margin that foreign inves-

\footnotetext{
${ }^{9}$ For more details, see: www.bcb.gov.br.

${ }^{10}$ About the relations between the onshore and offshore derivative markets see: Ma, Ho and McCauley (2004).
} 
tors must deposit, this margin should be increased and only cash deposits should be accepted (currently, domestic treasury bills are accepted). These broader regulations would curb speculative transactions in the domestic market and reduce the "communicating vessels" between the onshore and off-shore market ${ }^{11}$.

\section{REFERENCES}

AKYÜZ, A. (2011) "Capital flows to developing countries in a historical perspective: will the current boom end with a bust and how?"South Centre, Geneva.

BIANCARELI, André. (2009) "International liquidity cycles to developing countries in the financial globalization era”. Artigo apresentado na XI Reunión de Economía Mundial, 2009.

BIS (2010) Annual Report. Basle: Bank of International Settlements (Chapter IV).

Blanchard, O.; Dell'Ariccia, G; Mauro, P. "Rethinking Macroeconomic Policy;" IMF Staff Position Note SPN/10/03; 2010, February 12.

BRESSER-PEREIRA, Luiz Carlos. (2009) Globalização e Competição. Rio de Janeiro: Elsevier.

EPSTEIN, G., GRABEL, I. and JOMO. K.S. (2004) "Capital management techniques in developing countries: an assessment of experiences from the 1990s and lessons for the future". G-24 Discussion Paper no. 27, 2004. Geneva, United Nations Conference on Trade and Development.

FLASSBECK, H. (2001) “The exchange rate: economic policy tool or market price?” Geneve: United Nations Conference on Trade and Development (Unctad Discussion Paper, n. 157), November.

HELLEINER, E. (1994) States and the Reemergence of Global Finance, from Bretton Woods to the 1990's. Ithaca and London: Cornell University Press, 1994.

KEYNES, J.M. Activities 1940-1944: shaping the Post-War World, the Clearing Union. London, Macmillan, 1980 (The Collected Writings of John Maynard Keynes, v. 26, ed. by Moggridge, D.).

MA, GUONAN; HO, CORRINNE AND MCCAULEY, ROBERT N. (2004): "The markets for non deliverable forwards in Asian currencies", BIS Quarterly Review, available in http://www.bis.org

MCCAULEY, R.; SCATIGNA, M. (2011) "Foreign exchange trading in emerging currencies: more financial, more offshore”. In: BIS. Quartely Review.

OSTRY, J. et al. (2010) "Capital Inflows: the role of controls". IMF Staff Position Note. Washington, D.C. International Monetary Fund.

PRATES, D.M.; CINTRA, M.A.M. (2010) "The emerging-market countries in the face of the global financial crisis". In: Dullien, S. (ed.). Financial and Economic Crisis of 2008-2009 and The developing Countries. Genève-Berlin: UNCTAD/DAAD network publication, 2010. Available in: www.unctad.org.

PRATES, D.M., FARHI, Maryse. (2009) “A crise financeira internacional, o grau de investimento e a taxa de câmbio do real". Campinas: Instituto de Economia (Texto para Discussão n. 164).

RODRIK, D. (2006) "The social cost of foreign exchange reserves". NBER Working Paper no. 11952. Cambridge, MA, National Bureau of Economic Research. Available at: http://www.nber.org/papers/w11952.

\footnotetext{
${ }^{11}$ It is worth to mention that with respect to the "Exchange rate management techniques", only on 27 July 2011 (after the Real reached a 12-year high against the dollar) a more comprehensive "Exchange rate management technique" was adopted. The government extended its IOF on currency derivatives, which will be charged at a rate of $1 \%$ on changes in net long real positions with a notional value of over USD10 million. Net long real positions with a notional value of $\$ 10$ million or less are exempt from the tax.
} 